\title{
ELABORATION OF AN EROSION MAP USING THE ANALYTICAL HIERARCHY PROCESS (AHP) CASE OF THE REGION OF CONSTANTINE (ALGERIA)
}

\author{
Guellouh SAMI * \\ Dr. Laboratory LRNAT, university of Batna -02-, Algeria, \\ e-mail: guellouhsami@gmail.com \\ Filali ABDELWAHHAB \\ Dr. Laboratory LRNAT, university of Batna -02-, Algeria, \\ e-mail: abdelwahhabfilali@gmail.com \\ Kalla Mouhamed ISSAM \\ Dr. Laboratory LRNAT, university of Batna -02-, Algeria, \\ e-mail: kalla.issam@yahoo.fr
}

Citation: Sami, G., Abdelwahhab, F., \& Issam, K., M. (2020). Elaboration of an Erosion Map Using the Analytical Hierarchy Process (AHP) Case of the Region of Constantine (Algeria). Analele Universităţii din Oradea, Seria Geografie, 30(1), 1-9. https://doi.org/10.30892/auog.301101-809

\begin{abstract}
A multi-criteria Analytical Hierarchy Process (AHP) analysis was carried out using a geographic information system (GIS) integrating several factors, namely slope, geology, annual average rainfall and land use, which effects interfere and act on erosion dynamics of the Wilaya (province) of Constantine. The objective of this study is to better understand this phenomenon through an accurate assessment and spatialization of the level of vulnerability in this region.
\end{abstract}

Key words: AHP, Constantine, erosion dynamics, GIS, vulnerability

$* \quad * \quad * \quad * \quad * \quad *$

\section{INTRODUCTION}

Soil erosion consists of the detachment and transport of soil particles through the usually combined mechanical action of rainfall and runoff (Dumas, 2010). This phenomenon is widespread among the different Mediterranean basin countries (Kheir et al, 2001). The factors involved in the erosion process are grouped into four domains: topography, soil, land use and climate (Wischmeier et al., 1978).

Constantine is one of the Algerian Wilayas where erosion poses a serious threat, as it is located in a very sensitive sector given the presence of a pronounced relief, soft lithology, propitious climatic conditions and a land use that does not meet the prevailing landscape

\footnotetext{
${ }^{*}$ Corresponding Author
} 
conditions. We have tried to summarize in this work the effect of these factors, which are different in nature, using an AHP analysis in order to spatialize the vulnerability of the landscape to erosion in a precise way. AHP is a method of spatial analysis that combines several criteria, of a different nature, in order to obtain a cartographic result indicating areas more or less capable of solving the problem (Balzarini et al., 2011).

The adopted method is AHP. The analytical hierarchy process (Saaty, 1980) is a multicriteria decision analysis method that solves decision making problems by ranking alternatives according to several criteria (Cozannet et al, 2013). This method has been worldwide applied in many domains to determine the importance of certain factors in solving some problems or making important decisions (Hapciuc et al, 2016). The selection of criteria that has spatial reference is an important step in spatial multicriteria decision analysis (Malczewski, 1996).

\section{STUDY AREA}

The Wilaya of Constantine is located in Eastern Algeria, $431 \mathrm{~km}$ east of the capital, Algiers. It covers an area of 2,248.44 $\mathrm{km}^{2}$, between $35^{\circ} 7^{\prime}$ and $36^{\circ} 9^{\prime}$ north and between $6^{\circ} 20^{\prime}$ and $7^{\circ} 29^{\prime}$ east. The climate is of continental type and is characterized by hot dry summers and cold and wet winters with annual rainfall varying between 450 and $780 \mathrm{~mm}$ and a maximum daily precipitation exceeding $160 \mathrm{~mm}$. The territory of this region is essentially agricultural.

The reliefs can be subdivided into three large sets namely:

- a mountain range north of the Wilaya with an altitude of up to $1200 \mathrm{~m}$, with a majority of formations being limestone and dolomite;

- just below the central area, there is a relief formed by hills, foothills and plains mainly made of relatively soft lithologic formations.

- a mountain range south of the Wilaya which altitude varies between 1000 and $1300 \mathrm{~m}$ which is characterized by a complex lithological structure and morphology.

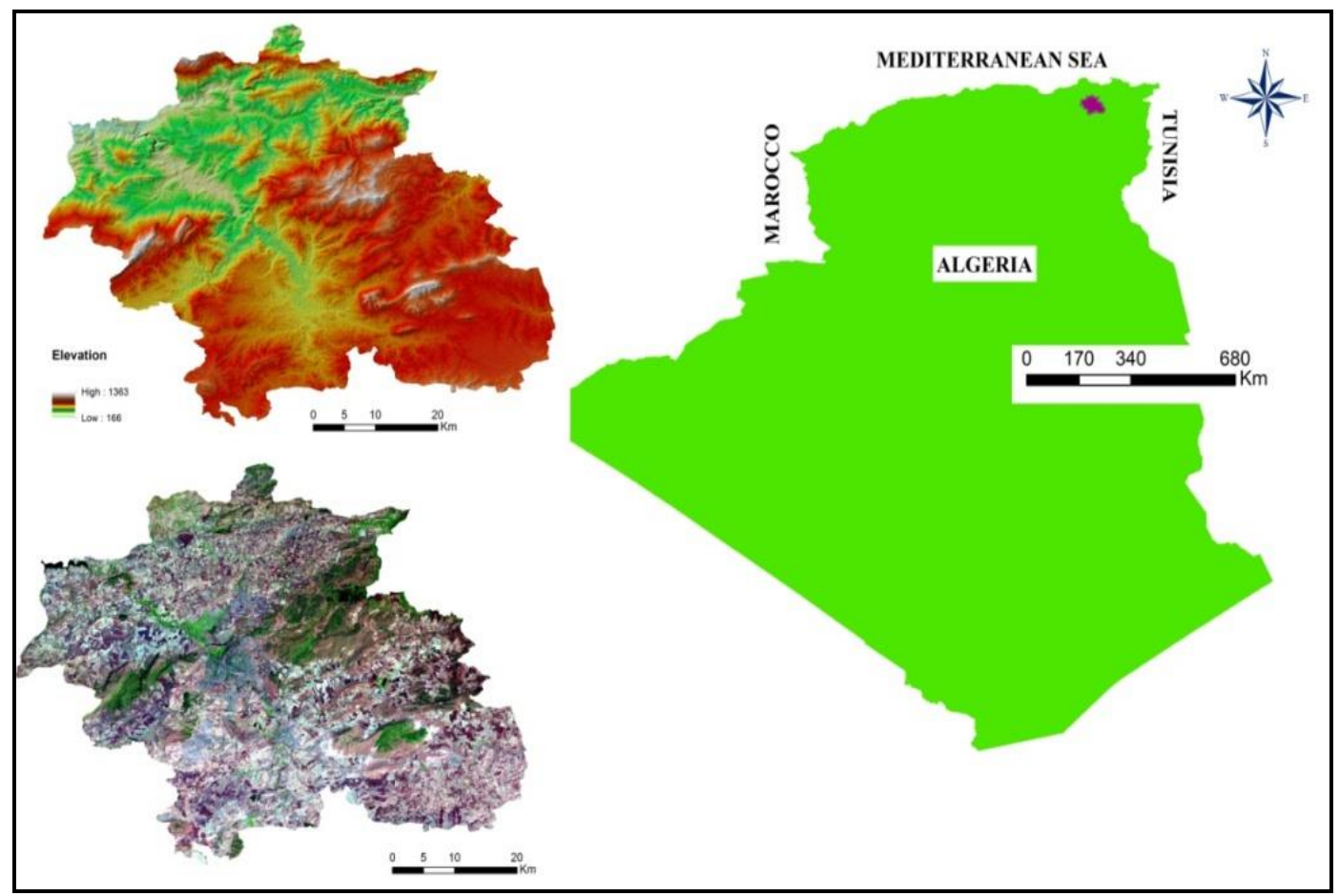

Figure 1. Study area

(Source: Guellouh Sami) 


\section{MATERIALS AND METHODS}

The adopted method is AHP. It's i a popular method used as a tool for multi-criteria decision making (MCDM) or as a technical estimation (Taibi et al., 2017). This method has mathematical properties and allows total ranking, it requires a hierarchy of the decision problem and a pairwise comparisons of entities in every node of the hierarchy (Saaty, 2008). AHP involves the following steps: (1) structuring possible factors for the problem into a hierarchy; (2) arranging the factors for each alternative; (3) developing the criteria for alternatives; (4) evaluating the importance of alternatives; and (5) analyzing the weight of each factor (Chen et al, 2011).

The factors involved in the spatialization of vulnerability to the local erosion are listed in order of priority in the table below.

Table 1. Factors involved in the analysis

\begin{tabular}{|c|c|}
\hline Factors & weights \\
\hline Slope & $\mathrm{C} 1$ \\
\hline Lithological units & $\mathrm{C} 2$ \\
\hline Average annual rainfall & $\mathrm{C} 3$ \\
\hline Land use & $\mathrm{C} 4$ \\
\hline
\end{tabular}

\section{The slope}

The topographic slope strongly influences the amount and severity of runoff. Once the slope is sufficient to allow water to run off, the land is vulnerable to water erosion (Kheir et al., 2001). It greatly influences the importance of erosion by its gravitational action and provides water its erosive energy (Dumas, 2010).

Slope is a key factor in this analysis because areas in steep and very steep sectors are areas prone to erosion risk.

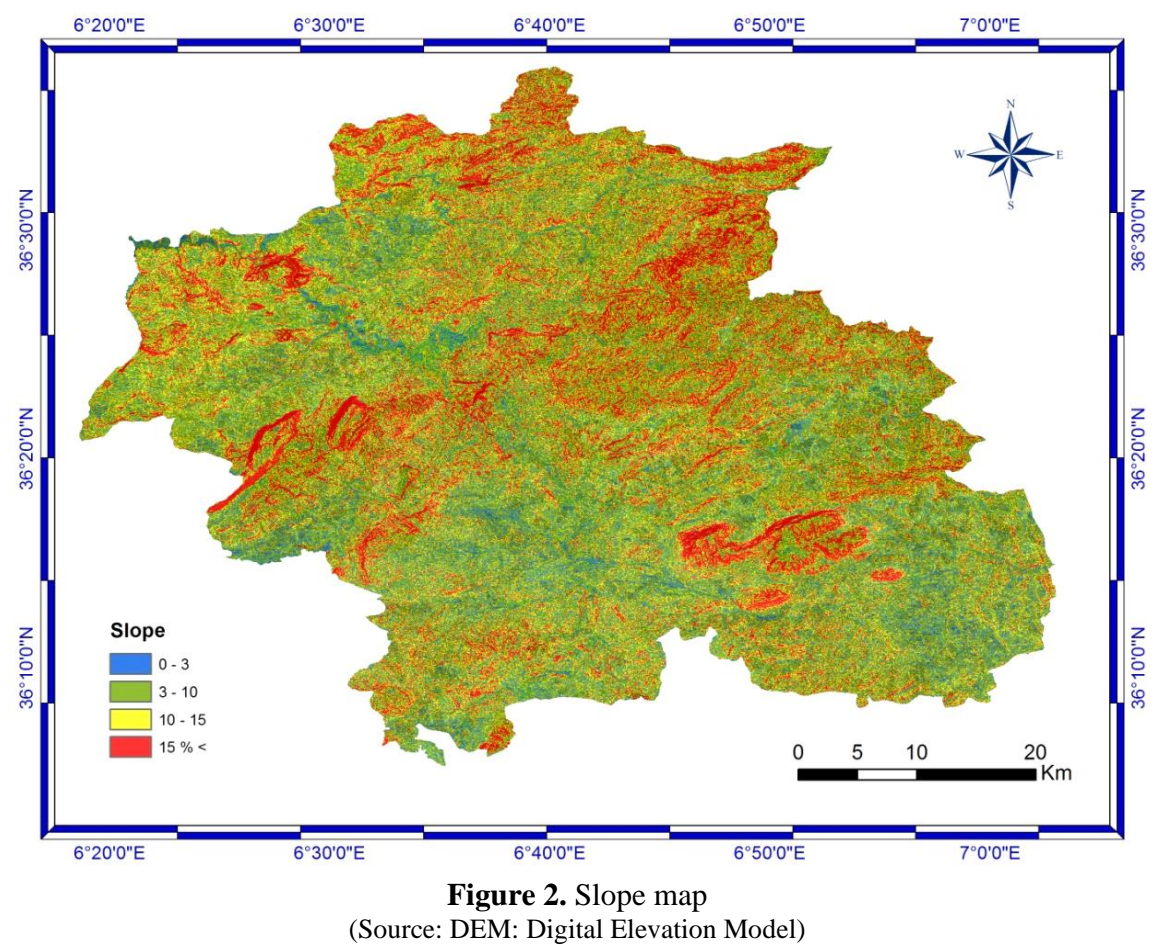


Table 2. Ranking of slope Influencing

\begin{tabular}{|c|c|c|}
\hline & Class of parameters & Ranking \\
\hline $0-3$ & Gentle & 1 \\
\hline $3-10$ & Moderate & 2 \\
\hline $10-15$ & Steep & 3 \\
\hline $15<$ & Very Steep & 4 \\
\hline
\end{tabular}

\section{The lithological formations}

The lithological quality of the formations and their spatial articulation determine the level of erodability of the reliefs and guides the action of the erosive processes.

On the basis of a 1/500 000 geological map of East Algeria, we were able to classify the soils according to their resistance in four classes.

Table 3. Friability classes of lithological formations

\begin{tabular}{|c|c|c|}
\hline Lithological formations & Materials friability & Ranking \\
\hline Dolomitic limestones & Resistant materials & 1 \\
\hline Limestones with marl and clay infills & Moderatelyresistant & 2 \\
\hline Sandstones and conlomerates & Vulnerablematerials & 3 \\
\hline Red clays and alluvium & Highly vulnerable materials & 4 \\
\hline
\end{tabular}

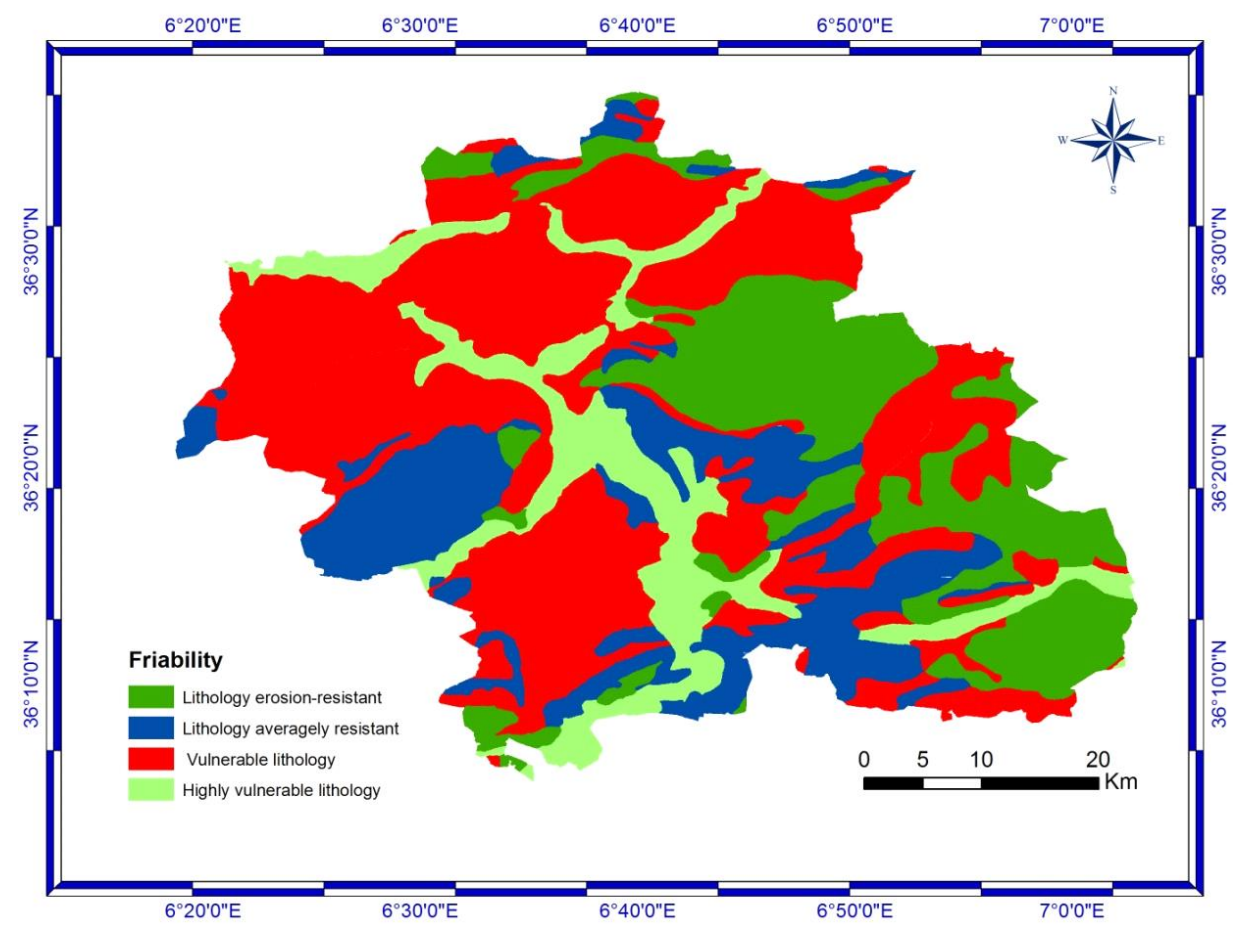

Figure 3. Friability map of lithological formations (Source: 1/500 000 geological map of East Algeria)

\section{Average annual rainfall}

The intensity and the spatio-temporal distribution of rainfalls are at the root of the onset of the erosion phenomenon.

When the runoff gathers in nets, the friction forces with the soil surface decrease; the runoff then acquires its own abrasive power and digs deeper and deeper channels (Roose, 1984). 
Table 4. Ranking of rainfall Influencing

\begin{tabular}{|c|c|}
\hline Rainfall (mm) & Ranking \\
\hline $445.3-500$ & 1 \\
\hline $500-600$ & 2 \\
\hline $600-700$ & 3 \\
\hline $700-770.5$ & 4 \\
\hline
\end{tabular}

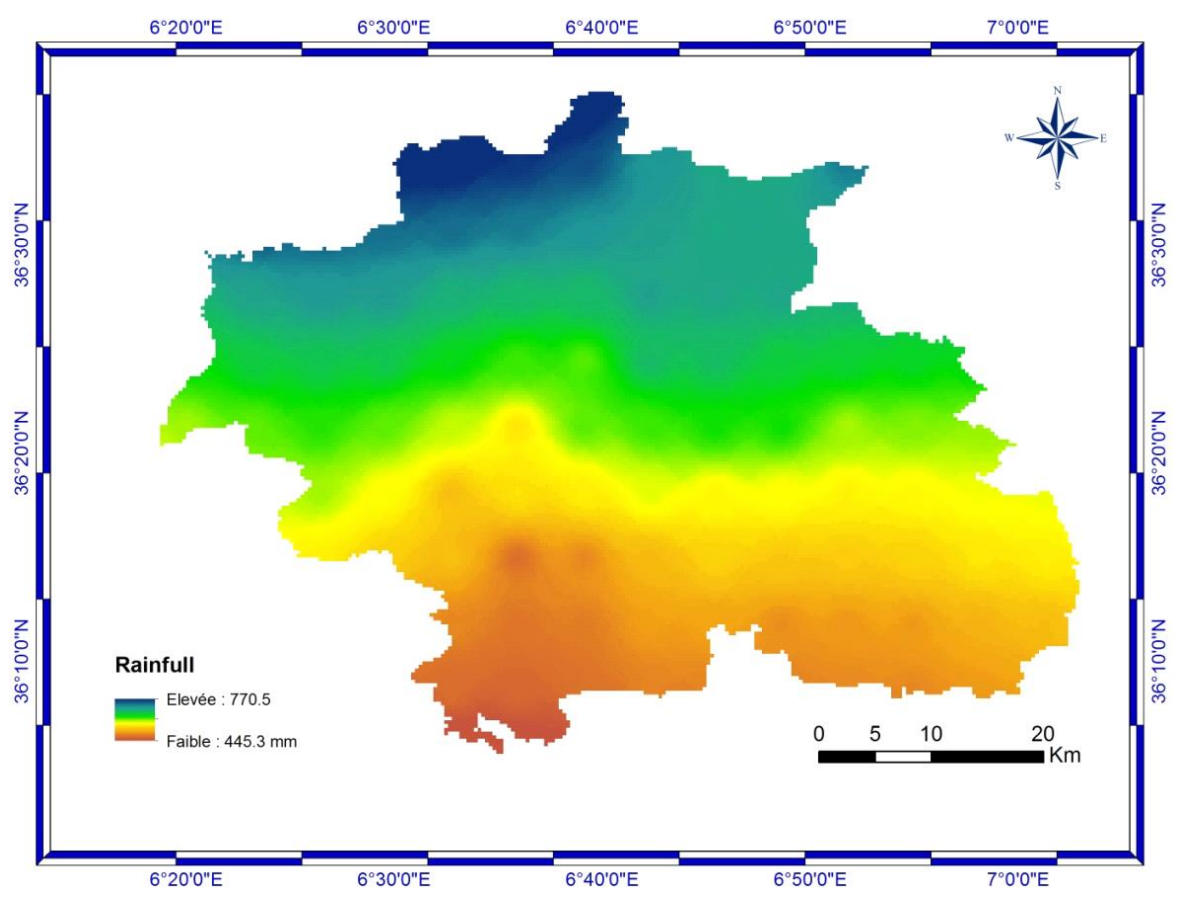

Figure 4. Annual average precipitations (Source: Guellouh Sami)

\section{Land use}

Land cover strongly controls all morphogenic processes. The erosion process is closely related to the land use pattern, which largely contributes to its erosion or mitigation. Land cover determines the degree of soil protection (Dumas, 2010). The land cover map was established by a supervised classification of a $30 \mathrm{~m}$ resolution ETM+ Land SAT 8 satellite image covering the entire study area.

Based on this classification, we were able to extract information about the spatial distribution of each land-use element.

Table 5. Ranking of land use influencing

\begin{tabular}{|c|c|}
\hline Land use & Ranking \\
\hline Dam & 0 \\
\hline Urban area & 0 \\
\hline Forest & 1 \\
\hline agricultural land & 3 \\
\hline Bare ground & 4 \\
\hline
\end{tabular}




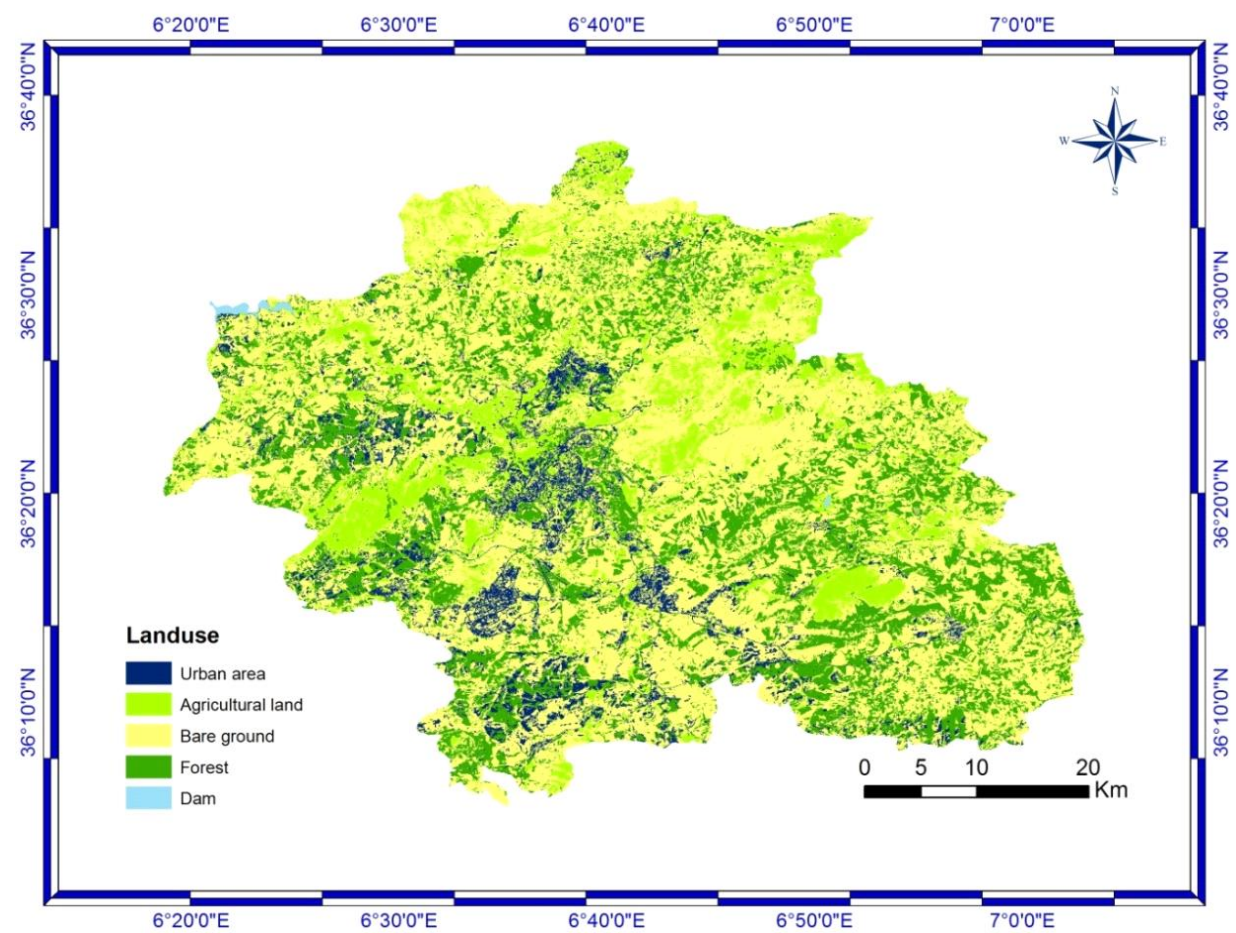

Figure 5. Land Cover Map

(Source: Land SAT 8 satellite image classification)

The pairwise comparisons of criteria are made using a scale of absolute judgments, commonly called Saaty's scale, which indicates how much one item predominates over another with respect to a given attribute (Cozannet et al, 2013). This scale transforms qualitative assessments into numerical values from 1 to 9 which are used to fi t the matrices. The priority scales are then derived by calculating the eigenvector associated with the main eigenvalue of each comparison matrix (Saaty, 1980).

Table 6. Pairwise comparison scale (Saaty, 1980)

\begin{tabular}{|c|c|c|}
\hline Importance & Definition & Explanation \\
\hline 1 & Equal importance & Two elements contribute equally to the objective \\
\hline 3 & Moderate importance & $\begin{array}{c}\text { Experience and judgment slightly favor one } \\
\text { Parameter over another }\end{array}$ \\
\hline 5 & Strong importance & $\begin{array}{c}\text { Experience and judgment strongly favor one } \\
\text { Parameter over another }\end{array}$ \\
\hline 7 & Very strong importance & $\begin{array}{c}\text { One parameter is favored very strongly and is } \\
\text { Considered superior to another; its dominance is } \\
\text { Demonstrated in practice }\end{array}$ \\
\hline 9 & Extreme importance & $\begin{array}{c}\text { The evidence favoring one parameter as superior to } \\
\text { Another is of the highest possible order of affirmation }\end{array}$ \\
\hline $2,4,6,8$ & \multicolumn{2}{|c|}{ Can be used to express intermediate values } \\
\hline
\end{tabular}

It should be noted that urban areas and aquatic environments (dams, lakes, etc.) are excluded from the analysis (zero vulnerability) and the weighting for the different classes of the same criterion is obtained in the same way as with the criteria between themselves. 


\section{RESULTS AND DISCUSSIONS}

The primary reason for the popularity of AHP for mapping the risk and its components is that the implementation of this technique within the GIS environment is straight forward, enabling the users to quickly derive the weights associated with criteria map layers (Malczewski, 2007). GIS with its capacity for storage, management, analysis, modeling and display of spatially referenced data, but also by its possibilities for integrating multicriteria spatial analysis methods, is presented as the tool more appropriate for understanding spatial decision-making problems (Chakhar, 2006).

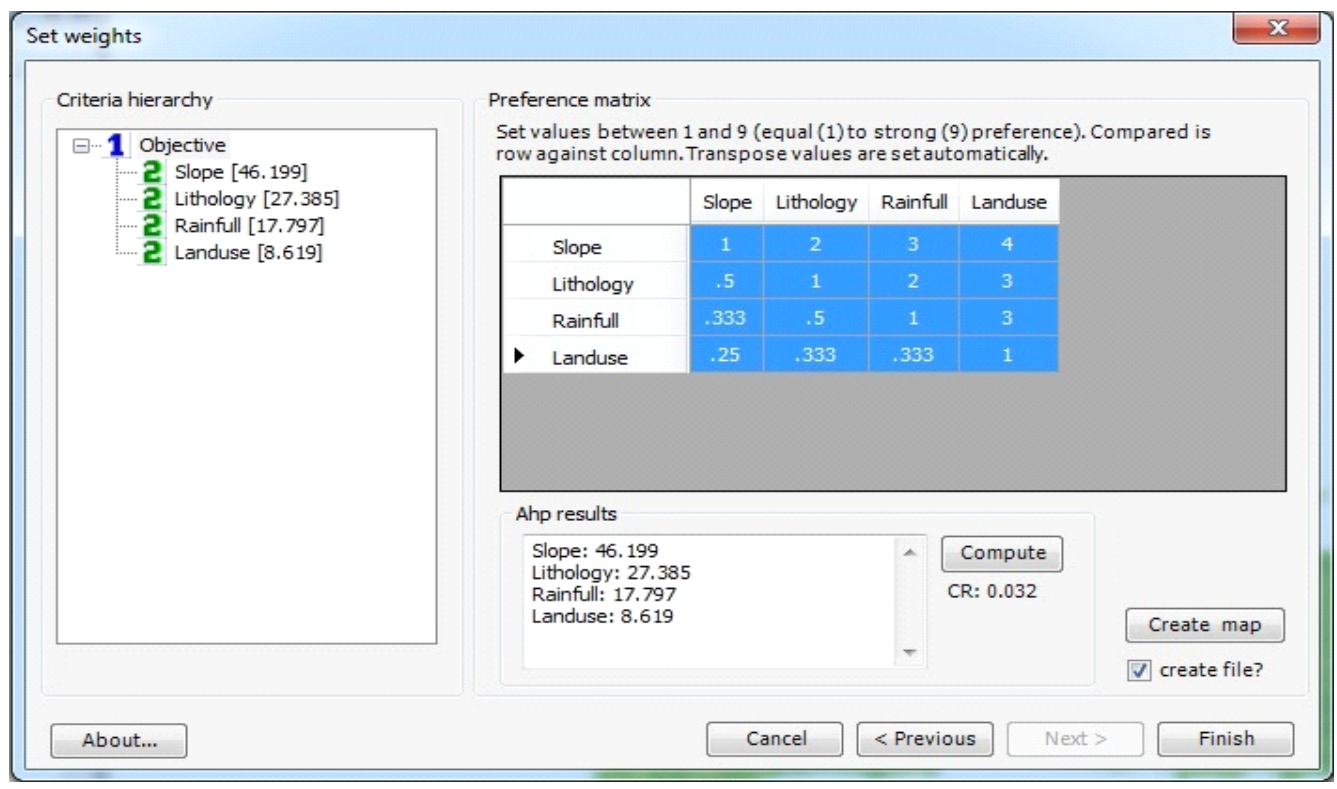

Figure 6. Comparison matrix under Arc Gis (Source: Guellouh Sami)

To ensure the consistency level of the judgments and that the data structures are logically related to each other, the ratio of coherence $\mathrm{CR}$ must be lower than the value 0.10 . The higher ratio of the value 0.10 indicates a higher level of inconsistency. In our case the $\mathrm{CR}=0.032$ (figure 5), which means an acceptable level of coherence.

The vulnerability to erosion is calculated according to the following formula:

$$
\text { Vulnerability }=0.461 \text { Slope }+0.273 \text { Lithology }+0.177 \text { Rainfall }+0.086 \text { Land use }
$$

The use of a GIS database allowed us to spatially quantify the level of vulnerability to erosion in a quantified way and to map complex phenomena from the data interaction (figure 7), which means that the methodology used can be used to carry out various planning tasks, allowing for a large amount of data to be used at different scales (Ramos et al, 2014).

Table 7. Surfaces and percentages of vulnerability classes

\begin{tabular}{|c|c|c|}
\hline Vulnerability & Areas in $\mathbf{k m}^{\mathbf{2}}$ & Ratio \\
\hline Zero & 163.54 & $7.27 \%$ \\
\hline Low & 123.32 & $5.48 \%$ \\
\hline Medium & 609.28 & $27.09 \%$ \\
\hline High & 961.11 & $42.75 \%$ \\
\hline Very high & 391.28 & $17.40 \%$ \\
\hline
\end{tabular}




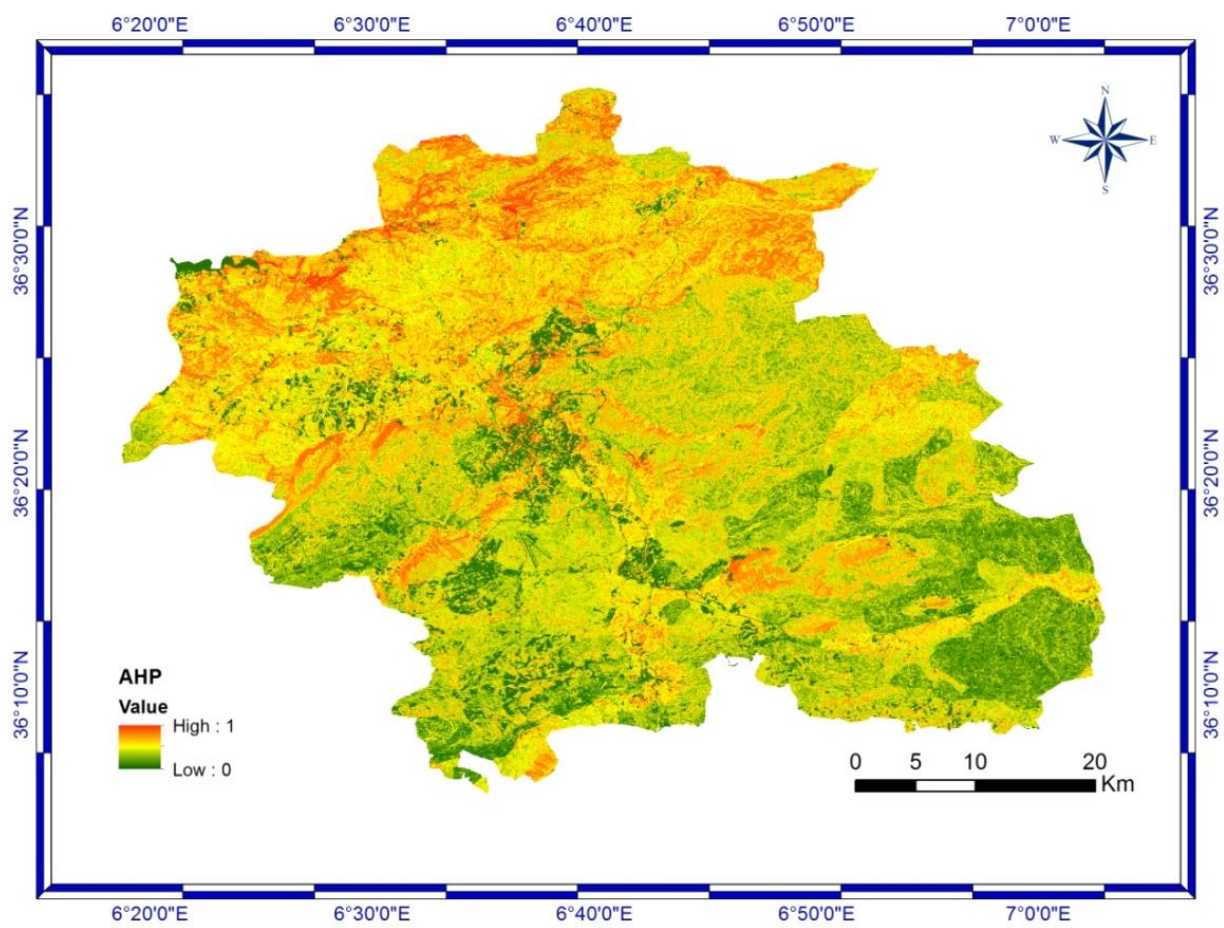

Figure 7. Erosion vulnerability map (Source: Guellouh Sami)

Field visits are necessary to validate this study and to ensure the reliability of the results of this method. The results show that surfaces showing high to very high vulnerability occupy more than $60 \%$ of the total area of the study area.

\section{CONCLUSION}

This study outlines the results of the application of the AHP method under a geographical information system (GIS) to map erosion vulnerability in the Wilaya of Constantine. The use of GIS is mainly based on the interaction of different types of data in order to extract relevant information on erosion vulnerability in cartographic form.

More than $60 \%$ of the surface of the Wilaya is recorded as being in a heavy to very heavy vulnerability area; this situation is favoured by the important cumulative influence of the different factors responsible for the triggering and the dynamics of the erosion process.

This method has shown reliability in the mapping of erosion vulnerability by several authors and can provide important assistance in terms of erosion control planning. It remains, however, subject to discussion on some aspects.

\section{REFERENCES}

Balzarini, R., Davoine, P. A., \& Ney, M. (2011, October). Évolution et développement des méthodes d'analyse spatiale multicritère pour des modèles d'aptitude: l'exemple des applications en Géosciences. In Conférence Francophone ESRI (pp. 1-19).

Chakhar, S. (2006). Cartographie décisionnelle multicritère: formalisation et implémentation informatique (Doctoral dissertation, Université Paris Dauphine-Paris IX).

Chen, Y. R., Yeh, C. H., \& Yu, B. (2011). Integrated application of the analytic hierarchy process and the geographic information system for flood risk assessment and flood plain management in Taiwan. Natural Hazards, 59(3), 1261-1276. 
Cozannet, G. L., Garcin, M., Bulteau, T., Mirgon, C., Yates, M. L., Méndez, M., ... \& Oliveros, C. (2013). An AHP-derived method for mapping the physical vulnerability of coastal areas at regional scales. Natural Hazards and Earth System Sciences, 13(5), 1209-1227.

Dumas, P. (2010). Méthodologie de cartographie de la sensibilité des sols à l'érosion appliquée à la région de Dumbéa à PaïtaBouloupari (Nouvelle-Calédonie). Les Cahiers d'Outre-Mer. Revue de géographie de Bordeaux, 63(252), 567-584.

Hapciuc, O. E., Romanescu, G., Minea, I., Iosub, M., Enea, A., \& Sandu, I. (2016). Flood susceptibility analysis of the cultural heritage in the Sucevita catchment (Romania). International Journal of Conservation Science, 7(2), 501-510.

Kheir, R. B., Girard, M. C., Shaban, A., Khawlie, M., FAOUR, G., \& Darwich, T. (2001). Apport de la télédétection pour la modélisation de l'érosion hydrique des sols dans la région côtière du Liban. Télédétection, 2(2), 79-90.

Malczewski, J. (1996). A GIS-based approach to multiple criteria group decision-making. International Journal of Geographical Information Systems, 10(8), 955-971.

Malczewski, J. (2006). GIS-based multicriteria decision analysis: a survey of the literature. International journal of geographical information science, 20(7), 703-726.

Ramos, A., Cunha, L., \& Cunha, P. P. (2014). Application de la Méthode de l'Analyse Multicritère Hiérarchique à l'étude des glissements de terrain dans la région littorale du centre du Portugal: Figueira da Foz-Nazaré. GeoEco-Trop, 38(1), 33-44.

Roose, E. (1984). Causes et facteurs de l'érosion hydrique sous climat tropical: conséquences sur les méthodes antiérosives. Machinisme Agricole Tropical, (87), 4-18.

Saaty, T. L. (1980). The analytic hierarchy process McGraw-Hill. New York, 324.

Saaty, T. L. (2008). Decision making with the analytic hierarchy process. International journal of services sciences, 1(1), 83-98.

Taibi, A., \& Atmani, B. (2017). Combining Fuzzy AHP with GIS and Decision Rules for Industrial Site Selection. International Journal of Interactive Multimedia \& Artificial Intelligence, 4(6), 60-69.

USGS (2017). Land SAT 8 satellite image and Digital Elevation Model.

Wischmeier, W. H., Walter, H., \& Smith, D. D. (1978). Predicting rainfall erosion losses: a guide to conservation planning (No. 537). Department of Agriculture, Science and Education Administration.

*** 1/500 000 geological map of East Algeria.

Submitted:

May 05, 2019
Revised:

December 02, 2019
Accepted and published online January 13, 2020 